\title{
Pre- and Postemergence Herbicide Tolerance of Tropical Fimbry, a Native Hawailan Sedge with Potential Use for Roadside Revegetation
}

\author{
Orville C. Baldos ${ }^{1,3}$, Joseph DeFrank ${ }^{1}$, and Glenn Sakamoto ${ }^{2}$
}

ADDITIONAL INDEX WORDs. oxadiazon, oryzalin, aminopyralid, roadside weed management, button sedge, Fimbristylis cymosa

SUMMARY. Tropical fimbry (Fimbristylis cymosa) is a salt, wind, and drought tolerant sedge under consideration as a native roadside revegetation species in Hawaii. Multiple rate studies were conducted on transplanted tropical fimbry plugs to identify pre- and postemergence herbicides that are safe for selective weed control during plant establishment. The response of newly transplanted tropical fimbry plugs to applications [ 1 and 44 days after transplanting (DAT)] of oxadiazon (2.0 and $4.0 \mathrm{lb} / \mathrm{acre})$, oryzalin $(2.0$ and $4.0 \mathrm{lb} / \mathrm{acre})$, and oxadiazon + oryzalin $(2.0+$ 2.0 and $4.0+4.0 \mathrm{lb} /$ acre) were evaluated at $212 \mathrm{DAT}$ through visual vigor ratings and seedhead counts. Response of established transplants to the postemergence broadleaf herbicides, aminopyralid ( 0.06 and $0.11 \mathrm{lb} /$ acre $)$ sulfosulfuron $(0.06 \mathrm{lb} /$ acre), prepackaged mixes of carfentrazone-ethyl + (4-chloro-2-methylphenoxy)acetic acid (MCPA) + mecoprop + dicamba $(0.02+1.11+0.22+0.11 \mathrm{lb} / \mathrm{acre})$, and carfentrazone-ethyl $+2,4-\mathrm{D}+$ mecoprop + dicamba $(0.02+0.77+0.24+0.07 \mathrm{lb} /$ acre) were evaluated through visual vigor ratings 35 days after spraying (DAS).

Results of the preemergence study indicate that low rates of oxadiazon and oryzalin provided an acceptable level of growth suppression to the sedge ( $>60 \%$ visual vigor). Postemergence applications of the prepackaged formulations of carfentrazone-ethyl resulted in moderate to high foliar injury ( $46 \%$ to $74 \%)$ and plant mortality ( $17 \%$ to $23 \%)$. Plants treated with sulfosulfuron showed signs of stunting (visual vigor of $36 \%)$, but exhibited the least foliar injury (16\%) and no mortality. Plants treated with high and low recommended rates of aminopyralid exhibited very low injury ratings ( $1 \%$ to $2 \%)$ at 35 DAS. Results obtained from these preliminary studies identified oxadiazon, oryzalin, and aminopyralid as potentially safe for controlling weed species in transplanted tropical fimbry.

$\mathrm{R}$ oadside revegetation and roadside landscaping with native species have increased over the past decade because of growing

We thank the State of Hawaii Department of Transportation and the United States Department of Agriculture-Natural Resources Conservation Service for providing financial support for this research. We thank the staff at the Hoolehua Plant Materials Center on Molokai for providing planting materials and technical assistance. We also thank Melinda Moata, the staff at the University of Hawaii Waimanalo Research Station and the Magoon Research Facility for their assistance in conducting the experiments.

Mention of a trademark, company, or proprietary name does not constitute an endorsement, guarantee, or warranty by the University of Hawaii, the United States Department of Agriculture nor the Natural Resources Conservation Service or its employees and does not imply recommendation to the exclusion of other suitable products or companies

This paper is a portion of a Master's thesis submitted by Orville C. Baldos at the University of Hawaii at Manoa.

${ }^{1}$ Department of Tropical Plant and Soil Sciences, University of Hawaii at Manoa, St. John Plant Science Lab 102, 3190 Maile Way, Honolulu, HI 96822

${ }^{2}$ United States Department of Agriculture-Natural Resources Conservation Service Hoolehua Plant Materials Center, 4101 Maunaloa Highway, P.O. Box 236, Hoolehua, HI 96729

${ }^{3}$ Corresponding author. E-mail: obaldos@hawaii.edu. environmental awareness, recent plant material availability (Knapp and Rice, 1994), and active promotion by the Federal Highway Administration (Harper-Lore, 1996; Steinfeld et al., 2007). In Hawaii, the use of native species on roadsides is a relatively new endeavor (Baldos et al., 2010). Roadside establishment and seed production protocols are currently being developed for several native groundcovers and shrubs. Tropical fimbry (mau'u 'aki'aki in Hawaiian) is one of several native groundcover species considered by the Hawaii Department of Transportation for roadside revegetation.
Tropical fimbry is a tuft growing perennial sedge with short rhizomes and stiff, leathery leaves. It is indigenous to the coastal areas of the Pacific basin, including Australia, western Malesia, Pacific Islands, and the Neotropics (Wagner et al., 1999). In Hawaii, it is commonly found growing on sandy beaches and rocky outcrops close to the ocean.

Certain characteristics of tropical fimbry make it a potential native groundcover for roadsides and landscapes. Its unusual leaf texture and similarity in growth with dwarf mondograss (Ophiopogon japonicus) make it highly ornamental. In fact, it has been used as a native groundcover for commercial, residential, and resort landscapes in Hawaii. Besides its unique form, tropical fimbry also possesses salt, wind, and drought tolerance. Propagation of this species can be easily done using seeds. Its small seed size make it amenable to hydroseeding (Baldos, 2009).

Because of its compact size and relatively slow growth, successful roadside establishment of tropical fimbry will require safe and effective weed control methods. Providing a weedfree environment during early establishment is essential for this native sedge to persist and exclude future weed invasions. To develop a weed management protocol specific to this species, safe and effective pre- and postemergence herbicides labeled for roadside use need to be identified. The studies in this preliminary and regional report characterized the response of tropical fimbry to the preemergence herbicides, oryzalin and oxadiazon, and to the postemergence herbicides, carfentrazone-ethyl + MCPA + mecoprop + dicamba, carfentrazone-ethyl + 2,4-D + mecoprop + dicamba, aminopyralid, and sulfosulfuron.

Oryzalin is a soil applied preemergence herbicide that is labeled for use on nonbearing fruit and nut crops, vineyards, rights-of-way areas

\begin{tabular}{llll}
\hline $\begin{array}{l}\text { Units } \\
\begin{array}{l}\text { To convert U.S. to SI, } \\
\text { multiply by }\end{array}\end{array}$ & U.S. unit & SI unit & $\begin{array}{l}\text { To convert SI to U.S., } \\
\text { multiply by }\end{array}$ \\
\hline 0.3048 & $\mathrm{ft}$ & $\mathrm{m}$ & 3.2808 \\
3.7854 & gal & $\mathrm{L}$ & 0.2642 \\
9.3540 & gfrgal/acre & $\mathrm{L} \cdot \mathrm{ha}^{-1}$ & 0.1069 \\
2.54 & inch(es) & $\mathrm{cm}$ & 0.3937 \\
25.4 & inch(es) & $\mathrm{mm}$ & 0.0394 \\
1.1209 & lb/acre & $\mathrm{kg} \cdot \mathrm{ha}^{-1}$ & 0.8922 \\
6.8948 & psi & $\mathrm{kPa}$ & 0.1450
\end{tabular}


such as roadsides as well as in Christmas tree plantations and landscape nurseries (Senseman, 2007). It controls many annual grasses and broadleaf weeds, including barnyardgrass (Echinochloa crus-galli), crowfootgrass (Dactyloctenium aegyptium), junglerice (Echinochloa colona), goosegrass (Eleusine indica), common purslane (Portulaca oleracea), and puncturevine (Tribulus terrestris) (United Phosphorus, 2004). Oxadiazon is another soil applied preemergence herbicide labeled for use in established and newly established turf as well as various ornamental crops (Senseman, 2007). It controls many annual broadleaf and grassy weeds, including sowthistle (Sonchussp.), creeping woodsorrel (Oxalis corniculata), and goosegrass (Bayer Crop Science, 2002).

Carfentrazone-ethyl + MCPA + mecoprop + dicamba, carfentrazoneethyl + 2, 4-D + mecoprop + dicamba, aminopyralid, and sulfosulfuron are selective postemergence herbicides that mainly control broadleaf weeds. Carfentrazone-ethyl + MCPA + mecoprop + dicamba is a herbicide formulation also known under the registered tradename, Powerzone ${ }^{\circledR}$ (PBI/Gordon Corp., Kansas City, MO). It is especially formulated for broadleaf weed control in warm and cool season turf in institutional, ornamental, and residential areas as well as commercial sod production sites and noncropland sites such as roadsides (PBI/Gordon Corp., 2008). Broadleaf weeds controlled by the said formulation include beggarticks (Bidens sp.), broadleaf plantain (Plantago major), buckhorn plantain (Plantago lanceolata), creeping woodsorrel, and puncturevine. Carfentrazoneethyl + 2,4-D + mecoprop + dicamba is another postemergence broadleaf herbicide formulation specifically developed for turf. It is registered under the tradename, Speedzone $\AA$ (PBI/ Gordon Corp.). Areas for use and species controlled by Speedzone ${ }^{\circledR}$ are similar to Powerzone $\AA$. The main difference between the two carfentrazone-based formulations is the type and amount of the second a.i. [i.e. Speedzone ${ }^{\circledR}$ contains MCPA, while Powerzone ${ }^{\circledR}$ contains 2,4-D]. Aminopyralid is a postemergence herbicide specifically used for broadleaf weed control in rice (Oryza sativa), wheat (Triticum sp.), oil palm (Elaeis guineensis), and rubber (Hevea brasiliensis) as well as in natural areas, rangelands, permanent grass pastures, and industrial vegetation management areas such as roadsides (Senseman, 2007). Weed species controlled by aminopyralid include spiny amaranth (Amaranthus spinosus), beggarticks, and flaxleaf fleabane (Conyza bonariensis) (Dow AgroSciences, 2008). Besides functioning as a postemergence herbicide, aminopyralid also has some preemergence activity on these weed species. Sulfosulfuron is a selective postemergence herbicide that controls many broadleaf weeds (Senseman, 2007) as well as sedge species such as green kyllinga ( $K y l$ linga brevifolia), purple nutsedge (Cyperus rotundus), and yellow nutsedge (Cyperus esculentus) (Monsanto, 2008). It is labeled for use in several cool and warm season turfgrasses as well as some warm season native grasses (Senseman, 2007).

\section{Materials and methods}

Preemergence tolerance STUDY. The preemergence study was carried out from Nov. 2005 to June 2006 at the U.S. Department of Agriculture-Natural Resources Conservation Service Plant Materials Center (NRCS PMC) in Hoolehua, HI. The predominant soil type found at the field site is Holomua silt loam (clayey, kaolinitic, isohyperthermic $\mathrm{Ty}^{-}$ pic Torrox). Tropical fimbry (Hoolehua NRCS PMC germplasm no. 9079806 ) plugs were prepared by planting seeds in 72-cell plastic trays filled with potting mix (ProMix 'BX'/Mycorise ${ }^{\circledR}$ Pro; Premier Tech Horticulture, Quakertown, PA). The tropical fimbry seeded into trays were allowed to germinate and grow under irrigated greenhouse conditions for $291 \mathrm{~d}$.

Before transplanting, the field was prepared by clearing the weeds and rototilling the soil. Tropical fimbry plugs (plants $\approx 6-\mathrm{cm}$ diameter) were transplanted into the prepared treatment plots (15-ft long by 6 - $\mathrm{ft}$ wide) as a single row with 2 - $\mathrm{ft}$ spacing in between plants (total of seven plants per treatment plot). The preemergence herbicide treatments, oxadiazon [2.0 and $4.0 \mathrm{lb} /$ acre (Ronstar $\AA 50 \mathrm{WP}$; Bayer Environmental Science, Research Triangle Park, NC)], oryzalin [2.0 and $4.0 \mathrm{lb} /$ acre (Surflan ${ }^{\circledR} 4 \mathrm{AS}$; United Phosphorus, Trenton, NJ)], and oxadiazon + oryzalin $(2.0+2.0$ and $4.0+4.0 \mathrm{lb} /$ acre) were applied 1 DAT. The herbicide treatments, which included an untreated control, were laid out in a randomized complete block with four replications. The herbicide treatments were sprayed over the designated plots using a three nozzle boom fitted with three Tee Jet 8004LP spray tips (Teejet Spraying Systems, Wheaton, IL). The 3-L sprayer, powered by an electric diaphragm pump (SHURflo, New Brighton, MN), was calibrated to apply $40 \mathrm{gal} / \mathrm{acre}$ at $15 \mathrm{psi}$. To ensure that no cross-contamination of herbicides occurred, the spray system was thoroughly rinsed with tap water between treatments. Overhead sprinkler irrigation was supplied daily to activate herbicides and ensure maximum growth and uniform establishment.

Based on soil tests, the entire experimental area was fertilized with $50 \mathrm{lb} /$ acre of $16 \mathrm{~N}-7 \mathrm{P}-13.3 \mathrm{~K}$ (Hikiola Cooperative, Hoolehua, $\mathrm{HI}$ ) at 14 DAT to enhance plug establishment. Forty-three $\mathrm{d}$ after the initial application of herbicides (44 DAT), the plots were handweeded and the preemergence treatments were reapplied to assess tolerance. Visual ratings of plant vigor $(0 \%=$ dead to $100 \%=$ no injury and showing $100 \%$ of maximum vigor) were recorded at $212 \mathrm{DAT}$. Seedheads from two plants per plot were also counted at 212 DAT as a physical measure of plant vigor.

Postemergence tolerance sTUDY. A field experiment to evaluate broadleaf postemergence herbicide tolerance was conducted after a greenhouse study by Baldos (2009) identified fluazifop-p-butyl as safe for grassy weed control in tropical fimbry. The field study was conducted from July to Sept. 2008 at the University of Hawaii Waimanalo Research Station in Waimanalo, HI. Soil types found in the field plots were Haleiwa silty clay (fine, mixed, isohyperthermic Typic Haplustoll) and Wailua clay (very fine, kaolinitic, isohyperthermic Typic Haplustoll). Because of the presence of these two soil types in the field, the treatments were blocked along the soil gradient. Land preparation began 1 year before the study was conducted. The area was limed (Dolomite 10 AG; Chemical Lime Co., Fort Worth, $\mathrm{TX})$ at a rate of $1949 \mathrm{lb} /$ acre $[54.7 \%$ calcium carbonate $\left(\mathrm{CaCO}_{3}\right), 42.6 \%$ magnesium carbonate $\left.\left(\mathrm{MgCO}_{3}\right)\right]$ and fertilized with $100 \mathrm{lb} /$ acre of 
8N-3.5P-6.6K (United Horticultural Supply; Loveland Products, Greeley, CO) and $200 \mathrm{lb} /$ acre of triple superphosphate $(0 \mathrm{~N}-20.1 \mathrm{P}-0 \mathrm{~K})$. After incorporating the soil amendments, the land was fallowed for 6 to 7 months. To exhaust the weed seed bank during the fallow period, weed growth induced by winter rains was treated with repeated spot spray applications of glyphosate (Roundup Pro®; Monsanto, St Louis) at $3.2 \mathrm{lb} /$ acre and triclopyr (Garlon 4; Dow AgroSciences, Indianapolis) at $1.6 \mathrm{lb} /$ acre. Any remaining weed seedlings were removed using a gardening hoe. Two months before planting, a 16 -ft-wide by $140-\mathrm{ft}$-long experimental area was laid out. An overhead irrigation system (Mamkad 16-ball driven sprinkler; Jain Irrigation, Fresno, CA) was installed to apply $10 \mathrm{~mm}$ of water per day.

One-year-old plugs of the sedge were planted at an in-row spacing of $2 \mathrm{ft}$ along five rows spaced $3 \mathrm{ft}$ apart. Immediately after planting, the plots were fertilized with $100 \mathrm{lb} /$ acre of $18 \mathrm{~N}-0 \mathrm{P}-15 \mathrm{~K}$ (United Horticultural Supply, Loveland Products) to facilitate plug establishment. A granular formulation of oxadiazon (Ronstar ${ }^{\circledR}$ G, Bayer Environmental Science) was also applied to the entire experimental planting at a rate of $2.0 \mathrm{lb} /$ acre for weed control during the establishment period. Before the postemergence herbicide treatments were applied, $6-\mathrm{ft}$ wide by $16-\mathrm{ft}$-long experimental units containing 15 plants (three rows with five plants each) were laid out.

At $70 \mathrm{DAT}$, the postemergence broadleaf herbicides, carfentrazoneethyl + MCPA + mecoprop + dicamba $[0.02+1.11+0.22+0.11 \mathrm{lb} /$ acre (Powerzone $\AA)$ ], carfentrazone-ethyl + 2,4-D + mecoprop + dicamba $[0.02+$ $0.77+0.24+0.07 \mathrm{lb} /$ acre (Speedzone) $]$, and sulfosulfuron $[0.06 \mathrm{lb} /$ acre (Certainty ${ }^{\circledR}$, Monsanto)] were applied using the same spray parameters (carrier volume and spray pressure) and equipment described in the preemergence study. The treatment plots, which included an untreated control, were laid out in a randomized complete block with four replications. Overhead irrigation was withheld $13 \mathrm{~h}$ after treatment application to allow for herbicide absorption. Visual ratings of vigor, foliar injury $(0 \%=$ no injury to $100 \%=$ complete plant death $)$, and green color $(0 \%=$ brown $/$ chlorotic to $100 \%=$ maximum attainable green color) as well as percent mortality were recorded 35 DAS.

Aminopyralid tolerance. The tolerance of tropical fimbry to low and high recommended rates of aminopyralid $[0.06$ and $0.11 \mathrm{lb} /$ acre (Milestone ${ }^{\circledR}$ VM, Dow Agrosciences)] was conducted from Oct. to Nov. 2008. Fifteen plants within the untreated control plots of the previous postemergence study (133 DAT) were divided into five rows containing three mature plants. The herbicide treatments plus an untreated control were laid out as a randomized complete block with four replications. Each treatment was randomly assigned to three of the five rows of plants available in each plot. Aminopyralid was applied using a single nozzle boom fitted with a Tee Jet 8004 spray tips attached to pump-up backpack sprayer (Birchmeier Backpack Sprayer; Birchmeier Sprühtechnik, Stetten, Switzerland). The sprayer was calibrated to apply $40 \mathrm{gal} / \mathrm{acre}$ at 13 psi. After treatment application, irrigation was withheld for $13 \mathrm{~h}$ to allow for herbicide absorption. Visual ratings of vigor, foliar injury, and green color were recorded 35 DAS.

Data Analysis. Analysis of variance (ANOVA) using statistical analysis software (Statistix ${ }^{\circledR}$ 9; Analytical Software, Tallahasee, FL) was performed for all data sets. Because of the significance for nonadditivity, vigor data from the preemergence study and foliar injury from the aminopyralid study were arcsine transformed and square root transformed, respectively before reanalysis. Tukey's range tests were performed on all data sets with a significant $\mathrm{F}$ test in the ANOVA.

\section{Results and discussion}

Preemergence study. Visual vigor ratings and seedhead counts at 212 DAT indicated that both oxadiazon and oryzalin were safe for preemergence weed control in transplanted tropical fimbry plugs. Except for plants treated with the high rate of oryzalin, plants treated with the preemergence herbicides did not exhibit significantly higher vigor ratings when compared with the untreated control plants. The highest vigor ratings were observed in plants treated with the high rate of oryzalin while the lowest vigor ratings were observed in the untreated plants (Table 1 ). The low vigor ratings recorded for the tropical fimbry in untreated plots were due to shading and competition from weeds. In terms of seedhead counts, no differences were observed between the untreated and preemergence herbicide treated tropical fimbry (Table 1 ). The degree of injury and stunting (based on visual vigor ratings) observed in this study are similar to other preemergence herbicide studies that were conducted in several herbaceous species (Baldos et al., 2010; Derr, 1994; Fain et al., 2006; Neal and Senesac, 1991). Oxadiazon was tolerated by container-grown grasses such as pampas grass (Cortaderia selloana) and fountain grass [Pennisetum setaceum (Neal and Senesac, 1991)] and wildflowers such as black-eyed Susan

Table 1. Percent visual vigor ratings and seedhead count of tropical fimbry plants treated twice ( 1 and $44 \mathrm{~d}$ after transplanting) with the preemergence herbicides, oxadiazon and oryzalin. The experiment was conducted from June 2005 to Nov. 2006 in Hoolehua, HI. Data were collected $211 \mathrm{~d}$ after the preemergence herbicides were initially applied $(n=4)$.

\begin{tabular}{lccc}
\hline $\begin{array}{l}\text { Preemergence herbicide } \\
\text { treatments }\end{array}$ & $\begin{array}{c}\text { Application } \\
\text { rate }(\mathbf{l b} / \mathbf{a c r e})^{\mathrm{z}}\end{array}$ & ${\text { Vigor }(\%)^{\mathrm{y}}}$ & ${\text { Seedheads (no. })^{\mathbf{x}}}^{\text {Oxadiazon }}$ \\
\hline Oxadiazon & 2.0 & $80 \mathrm{ab}^{\mathrm{w}}$ & $114^{\mathrm{v}}$ \\
Oryzalin & 2.0 & $66 \mathrm{ab}$ & 108 \\
Oryzalin & 4.0 & $63 \mathrm{ab}$ & 99 \\
Oxadiazon + Oryzalin & $2.0+2.0$ & $90 \mathrm{a}$ & 124 \\
Oxadiazon + Oryzalin & $4.0+4.0$ & $66 \mathrm{ab}$ & 80 \\
Untreated & - & $54 \mathrm{ab}$ & 72 \\
\hline
\end{tabular}

${ }^{\mathrm{z}} \mathrm{l} \mathrm{lb} / \mathrm{acre}=1.1209 \mathrm{~kg} \cdot \mathrm{ha}^{-1}$

Vigor rating was based on a visual scale of $0 \%$ to $100 \%$, where $0 \%=$ plant death and $100 \%=$ no injury and showing vigorous growth.

${ }^{\mathrm{x}}$ Means were calculated from total seedheads collected from two representative plants per replication.

"Means within column followed by the same letters are not significantly different as determined by Tukey's range test at $P<0.05$

No significant differences were observed among treatment means. 
Table 2. Visual ratings (vigor, foliar injury, and green color) and plant mortality of tropical fimbry $35 \mathrm{~d}$ after postemergence broadleaf herbicide applications. The experiment was conducted from July to Sept. 2008 at Waimanalo, HI.

\begin{tabular}{|c|c|c|c|c|c|}
\hline Postemergence herbicide treatments ${ }^{\mathrm{z}}$ & Application rate $(\mathrm{lb} / \mathrm{acre})^{\mathrm{y}}$ & Vigor $(\%)^{x}$ & $\begin{array}{c}\text { Foliar } \\
\text { injury }(\%)^{w}\end{array}$ & $\begin{array}{c}\text { Green } \\
\text { color }(\%)^{\mathrm{v}}\end{array}$ & Mortality (\%) \\
\hline Carfentrazone + MCPA + mecoprop + dicamba & $0.02+1.11+0.22+0.11$ & $54 b^{t}$ & $46 \mathrm{ab}^{\mathrm{t}}$ & $44 \mathrm{bc}^{\mathrm{t}}$ & $17 a b^{s}$ \\
\hline Carfentrazone + 2,4-D + mecoprop + dicamba & $0.02+0.77+0.24+0.07$ & $54 \mathrm{~b}$ & $74 \mathrm{a}$ & $21 \mathrm{c}$ & $23 \mathrm{a}$ \\
\hline Sulfosulfuron & 0.06 & $36 \mathrm{~b}$ & $16 \mathrm{~b}$ & $79 \mathrm{ab}$ & $0 \mathrm{~b}$ \\
\hline Untreated control & - & 89 a & $5 \mathrm{~b}$ & $95 \mathrm{a}$ & $0 \mathrm{~b}$ \\
\hline
\end{tabular}

${ }^{\mathrm{z}} \mathrm{MCPA}=$ (4-chloro-2-methylphenoxy)acetic acid, 2,4-D = 2,4-dichlorophenoxyacetic acid.

${ }^{y} 1 \mathrm{lb} /$ acre $=1.1209 \mathrm{~kg} \cdot \mathrm{ha}^{-1}$.

Vigor rating was based on a visual scale of $0 \%$ to $100 \%$, where $0 \%=$ plant death and $100 \%=$ no injury and showing vigorous growth.

"Foliar injury rating was based on a visual scale of $0 \%$ to $100 \%$, where $0 \%=$ no injury and $100 \%=$ plant death.

${ }^{v}$ Green color rating was based on a visual scale of $0 \%$ to $100 \%$, where $0 \%=$ brown/chlorotic and $100 \%=$ maximum attainable green color.

uPercent mortality was based on the ratio of dead plants to the total number of plants (15) within each treatment plot.

${ }^{\mathrm{t}} \mathrm{Means}$ within column followed by the same letters are not significantly different as determined by Tukey's range test at $P<0.01$.

s'Means within column followed by the same letters are not significantly different as determined by Tukey's range test at $P<0.05$.

(Rudbeckia birta var. pulcherrima) and blanketflower (Gaillardia aristata) (Derr, 1994). In contrast, growth reductions were observed for autumn fern (Cortaderia selloana) treated with oxadiazon (Fain et al., 2006). Sensitivity to oryzalin was observed in pampas grass and fountaingrass (Neal and Senesac, 1991) and in shasta daisy [Leucanthemum $\times$ superbum (Derr, 1994)].

Postemergence study. Spray applications of the four postemergence broadleaf herbicides caused varying levels of injury to tropical fimbry plants (Table 2). All postemergence herbicide treatments exhibited significantly lower plant vigor ratings compared with untreated plants. The lowest percent vigor ratings were recorded in sulfosulfuron treated plants (Table 2). Plants treated with carfentrazone + 2,4-D + mecoprop + dicamba and carfentrazone + MCPA + mecoprop + dicamba had vigor ratings of $54 \%$.

The highest foliar injury ratings were recorded for carfentrazone + 2,4-D + mecoprop + dicamba treated plants (Table 2). This was followed by carfentrazone + MCPA + mecoprop + dicamba treated plants. Foliar injury ratings recorded for sulfosulfuron treated plants were the lowest among the herbicides tested and were not different from injury ratings recorded in untreated plants.

The lowest percent green color ratings were observed in the carfentrazone + 2,4-D + mecoprop + dicamba treated plants (Table 2). This was followed by the carfentrazone + MCPA + mecoprop + dicamba treated plants (Table 3). Green color ratings recorded in sulfosulfuron treated plants were not different

Table 3. Visual ratings for vigor, foliar injury and green color of mature tropical fimbry treated with two rates of aminopyralid. Visual ratings were recorded 35 $\mathrm{d}$ after aminopyralid was applied. This experiment was conducted from Oct. to Nov. 2008 at Waimanalo, HI.

\begin{tabular}{|c|c|c|c|c|}
\hline Treatment & $\begin{array}{l}\text { Application } \\
\text { rate }(1 \mathrm{~b} / \text { acre })^{\mathrm{z}}\end{array}$ & Vigor $(\%)^{y}$ & $\begin{array}{c}\text { Foliar } \\
\text { injury }(\%)^{x}\end{array}$ & $\begin{array}{c}\text { Green } \\
\text { color }(\%)^{\mathrm{w}}\end{array}$ \\
\hline Aminopyralid & 0.06 & 92 & $1 a^{v}$ & $95 \mathrm{ab}^{\mathrm{u}}$ \\
\hline Aminopyralid & 0.11 & 91 & $2 \mathrm{a}$ & $93 \mathrm{~b}$ \\
\hline Untreated control & - & 94 & $0 \mathrm{~b}$ & $97 \mathrm{a}$ \\
\hline
\end{tabular}

${ }^{\mathrm{z}} \mathrm{l} \mathrm{lb} / \mathrm{acre}=1.1209 \mathrm{~kg} \cdot \mathrm{ha}^{-1}$.

${ }^{y}$ Vigor rating was based on a visual scale of $0 \%$ to $100 \%$, where $0 \%=$ plant death and $100 \%=$ no injury and showing vigorous growth. Mean vigor ratings were not significant.

${ }^{x}$ Foliar injury rating was based on a visual scale of $0 \%$ to $100 \%$, where $0 \%=$ no injury and $100 \%=$ plant death w Green color rating was based on a visual scale of $0 \%$ to $100 \%$, where $0 \%=$ brown $/$ chlorotic and $100 \%=$ maximum attainable green color.

${ }^{\mathrm{v}}$ Means within column followed by the same letters are not significantly different as determined by Tukey's range test at $P<0.01$.

"Means within column followed by the same letters are not significantly different as determined by Tukey's range test at $P<0.05$.

from those recorded in untreated plants.

The highest percent mortality was recorded in the carfentrazone + 2,4-D + mecoprop + dicamba treated plants followed by the carfentrazone + MCPA + mecoprop + dicamba treatments (Table 2). Sulfosulfuron was the only postemergence herbicide treatment that did not cause plant mortality.

Plants treated with carfentrazone + 2,4-D + mecoprop + dicamba exhibited the highest percent foliar injury, the lowest percent green color and highest plant mortality among the herbicides evaluated. The rapid development of injury symptoms was likely due to carfentrazone-ethyl, one of the four a.i. in the herbicide formulation. Functioning as a protoporphyrinogen oxidase enzyme inhibitor, carfentrazone-ethyl primarily controls broadleaf weeds through contact action (Boydston, 2004). The herbicide is rapidly absorbed by the leaves resulting in foliar necrosis and plant death
(Senseman, 2007). This mode of action contributed to the quick development of a bronzed appearance on foliage in the two carfentrazone-based treatments. On the other hand, auxinic herbicides in the formulation, primarily dichloroacetic acid (2,4-D), contributed to whole plant yellowing which eventually led to severe necrosis and plant death. Slightly less injurious than carfentrazone $+2,4-\mathrm{D}+$ mecoprop + dicamba was carfentrazone + MCPA + mecoprop + dicamba. According to Cavanaugh et al. (2009), MCPA has greater crop safety than 2,4-D since MCPA injury in barley (Hordeum vulgare) and wheat only occurs at high application rates.

Although plants treated with sulfosulfuron had the lowest foliar injury $(16 \%)$ and mortality $(0 \%)$, plants exhibited severe stunting. Sulfosulfuron is an acetolactate synthase inhibitor used mainly for controlling sedge species such as green kyllinga (Monsanto, 2008) and purple nutsedge (Eizenberg et al., 2003; Monsanto, 
2008). Herbicide damage caused by sulfosulfuron is often characterized by apical growth inhibition, progressing to leaf necrosis and total plant collapse (Eizenberg et al., 2003; Senseman, 2007). A reduction in shoot biomass and overall growth are also characteristic in species that are sensitive to sulfosulfuron (Monaco and Creech, 2004).

Aminopyralid tolerance. Visual ratings obtained 35 DAS indicate that mature tropical fimbry plants were tolerant to both high and low recommended rates of aminopyralid. Vigor ratings did not indicate any inhibitory effects of aminopyralid to tropical fimbry plants. Although foliar injury levels and green color ratings were significantly different between aminopyralid treated and untreated plants, the values were not substantial enough to cause detrimental impacts to mature plants (Table 3 ).

The results of this study have shown that tropical fimbry has considerable tolerance to several pre- and postemergence herbicides. Oryzalin and oxadiazon can be potentially used for preemergence weed control on newly transplanted tropical fimbry plugs, while aminopyralid has potential use for selective postemergence broadleaf weed control on wellestablished plants. Because of the preliminary nature of these results (i.e., the studies were not repeated in space or in time), it is recommended that further studies be done under several conditions to confirm safety to tropical fimbry.

\section{Literature cited}

Baldos, O.C. 2009. Assessment of hydroplanting techniques and herbicide tolerance of two native Hawaiian groundcovers with roadside re-vegetation potential. Univ. Hawaii at Manoa, Masters Thesis.

Baldos, O.C., J. DeFrank, and G. Sakamoto. 2010. Tolerance of transplanted seashore dropseed to pre- and postemergence herbicides. HortTechnology 20:772777.

Bayer Crop Science. 2002. Ronstar G herbicide label. Bayer Environmental Science, Montvale, NJ.

Boydston, R.A. 2004. Managing volunteer potato (Solanum tuberosum) in field corn (Zea mays) with carfentrazoneethyl and dicamba. Weed Technol. 18: 83-87.

Cavanaugh, K.J., B.R. Durgan, R.K. Zollinger, and W.A. Selberg. 2009. Herbicide and Nonherbicide Injury Symptoms on Spring Wheat and Barley. 8 Sept. 2009. <http://www.extension. umn.edu/distribution/cropsystems / DC6967.html>.

Derr, J.F. 1994. Weed control in containergrown herbaceous perennials. HortScience 29:95-97.

Dow AgroSciences. 2008. Milestone VM herbicide label. Dow AgroSciences, Indianapolis, IN.

Eizenberg, H., Y. Goldwasser, G. Achdary, and J. Hershenhorn. 2003. The potential of sulfosulfuron to control troublesome weeds in tomato. Weed Technol. $17: 133-137$.

Fain, G.B., C.H. Gilliam, and G.J. Keever. 2006. Tolerance of hardy ferns to selected preemergence herbicides. HortTechnology 16:605-609.

Harper-Lore, B. 1996. Using native plants as problem solvers. Environ. Mgt. 20:827-830.

Knapp, E.E. and K.J. Rice. 1994. Starting from seed: Genetic issues in using native grasses for restoration. Restor. Mgt. Notes 12:40-45.

Monaco, T.A. and J.E. Creech. 2004. Sulfosulfuron effects on growth and photosynthesis of 15 range grasses. Rangeland Ecol. Mgt. 57:490-496.

Monsanto. 2008. Certainty turf herbicide label. Monsanto, St. Louis, MO

Neal, J.C. and A.F. Senesac. 1991. Preemergent herbicide safety in containergrown ornamental grasses. HortScience 26:157-159.

PBI/Gordon Corp. 2008. Powerzone ${ }^{\circledR}$ herbicide label. PBI/Gordon Corp., Kansas City, MO

Senseman, S.A. 2007. Herbicide handbook, Weed Sci. Soc. Amer. Lawrence, KS.

Steinfeld, D., S. Riley, K. Wilkinson, T. Landis, and L. Riley. 2007. Roadside Revegetation: An Integrated Approach to Establishing Native Plants. 11 Nov. 2008. <http://www.wfl.fha.dot.gov/ programs/td/publications/documents/ managers-guide.pdf $>$.

United Phosphorus. 2004. Surflan ${ }^{\circledR}$ AS herbicide label. United Phosphorus Inc., Trenton, NJ.

Wagner, W.L., D.R. Herbst, and S.H. Somer. 1999. Manual of flowering plants of Hawaii. Univ. Hawaii Press, Honolulu, HI. 